him in his home. Nevertheless, the extension of the school's responsibility increases the influence of the school in health as well as in education.

The whole report points strongly by implication to the need for a more dynamic and functional approach to school medicine.

One looks forward to the day when the school medical officer is an integral member of the school staff, whose duty it is to study the child at work and at play in the changing school setting. With its demands upon the child's senses and its opportunities for expression-intellectual, emotional and socialaspirations and powers, the school offers probably unique opportunity for the study of the functioning of the total child. The study of health in this dynamic sense would surely be much more profitable than the present sporadic and static methods of school medical inspection.

\section{INDUSTRIAL FIBRES}

$\mathrm{B}$ EFORE the Second World War, the Commonwealth Economic Committee issued annually a series of reviews which summarized the main facts of production, international trade and consumption for various important animal and plant commodities. These reviews are now being re-issued for the war and post-war years. Among the first to reappear is the volume on "Industrial Fibres"*, which surveys the world situation with regard to cotton, wool, silk, flax, jute, hemp, mohair, coir and rayon. While the data for several countries are not yet available, the information gives a broad indication of changing trade patterns. The main change has been the redirection of foreign trade caused by the dislocation of normal trading channels and the development of alternative sources of supply. The United Kingdom remained the chief importer of industrial fibres, although, after 1941, the United States imported most wool, some of which was accumulated as reserve on the United Kingdom's account. Imports into the main European countries and Japan were greatly reduced during the war years.

The world production of fibres at first expanded but soon declined sharply, reaching a minimum in 1944, with moderate recovery in 1946. Output was generally restricted to cover essential war purposes, and civilian consumption of textiles was curtailed. Where production exceeded demand, as in wool and cotton, stocks accumulated, thus increasing the supplies available in the post-war period. The recovery in 1946 continued in 1947, but future expansion will depend on changing conditions in Germany and Japan. There has been no significant modification in the post-war pattern of production of the different fibres compared with pre-war years, with the exception of rayon, which is now being mainly produced in the United States. Comparing production in 1945 with that in 1938, wool has declined least, namely, 2 per cent; rayon yarn has declined 11 per cent; cotton 26 per cent; staple rayon fibre 45 per cent; and silk 73 per cent. The serious decline in cotton production was caused mainly by the transfer of cotton-growing land to food production, particularly in India and the United States. Silk production was largely suspended in Japan during the War. In 1946,

* Industrial Fibres. Summary of Figures of Production, Trade and Consumption relating to Cotton, Wool, Silk, Flax, Jute, Hemp, Mohair, Coir and Rayon. Compiled in the Intelligence Branch of the Commonwealth Economic Committee. Pp. 137. (London: H.M. Stationery Office, 1948.) wool alone showed a small decline over the 1945 figure, but world stocks are still large. Rayon made good the war-time losses and rose 10 per cent above the 1938 figure. Cotton and staple fibre production also showed improvements but silk expanded only slightly, being in 1946 only 27 per cent of the prewar figure.

The contribution made by the British Commonwealth to the world's production of fibres is considerable. Thus nearly all the world's jute, nearly half the world's wool, more than a quarter of all its hemp and nearly a fifth of its cotton are produced in the Commonwealth, which is still an exporter of these fibres, having built up surplus stocks before the War. The 1946 export balance for wool was the highest ever recorded; for jute and hemp it was about one-half of the pre-war figure. The war-time dependence on foreign supplies of rayon, silk and flax (imported on balance before the War) has now been lessened, but dependency on outside sources still applies to cotton.

The significance of industrial fibres in the exports of different Commonwealth countries has been amply maintained during the post-war period. For example, wool accounted in 1946 for 33 per cent of the total exports of South Africa, other than gold, as compared with 30 per cent in 1938 and only 6 per cent in 1944. Jute and jute products made up nearly 30 per cent of the exports from India in 1946, which were 24 per cent in 1938 . Hemp reached 44 per cent of the exports from Tanganyika in 1946 as against 38 per cent in 1938 .

Cotton. The main sources of cotton for world trade wre the United States, India, Brazil and Egypt. In addition, Russia and China also grow large quantities of cotton but consume most of it domestically. The chief importers of cotton before the War were Japan and the United Kingdom, which used up nearly half the total production, other European countries consuming the rest. Production declined from 17,900 million $\mathrm{lb}$. in 1938 to 10,000 million $\mathrm{lb}$. in 1946 , but consumption fell even more, so that stocks rose from 10,400 to 13,500 million lb., but have since fallen to nearly half this amount. Long-staple varieties are being increasingly grown in most of the chief areas.

Wool. This is produced as a main product in merino sheep farming or as a secondary product to meat in the rearing of crossbreds. A dry summer greatly reduces the output of fine merino wool. The rising trend in number of sheep before the War was reversed in 1941, and the decline was accentuated by the Australian drought of 1944-45. World production of wool fell rapidly after 1942, especially in the United States and Australia, and to a lesser extent in South Africa. Australia still retains its position as the leading wool-exporting country and usually exports more than twice as much wool as any other country. The chief importing country until 1941 was the United Kingdom, but since that year the United States has assumed first place. Lack of production statistics for mohair renders it difficult to assess the changes in world supplies over the war period.

Silk. Before the War, some 100 million lb., or 80 per cent, of the world's silk was produced in Japan. Since 1941, the production has diminished rapidly until, in 1946, Japan produced only 12 million lb. of raw silk. Even before the War, production was declining through increasing competition with rayon and nylon, which may eventually supersede natural silk. 
Flax. The best flax is produced in temperate regions such as Europe. In certain countries, the plant is grown primarily for linseed, the fibre being a relatively expensive by-product. Reliable information concerning the world's flax industry is difficult to obtain because of this dual-purpose objective. The output of flax appears to have declined by some 70 per cent up to 1945 and has since shown only a moderate recovery. Considerable reduction in output has occurred in Russia, Poland, Belgium and Holland, whereas it has expanded in Egypt, Australia, New Zealand and Canada. Cotton, jute and rayon are proving to be serious competitors of flax, partly because of the high price of linen goods.

Hemp. The chief hemp-producing countries before the War were the Philippine Islands (manila bast fibre, used for marine cordage), the Netherlands East Indies and Tanganyika (sisal bast fibre, used for binder twine), Eastern Europe and Russia (true, leaf hemp, used for twine and cord). World output of bast (or 'hard') hemps fell considerably through the effects of the War in the Far East, although the out. put in Tanganyika was maintained, and of leaf (or 'soft') hemp in Europe and Russia through curtailment of the area on which the crop was grown.

Jute. Most of the world's jute is grown in Pakistan, but the greatly increased home demand for sacking has brought about a marked reduction in exports. The jute mills and the main port (Calcutta) are situated in the Dominion of India, and future development of the jute industry will depend on the conditions of inter-trade between the two new Indian Dominions. The largest importer of jute is the United Kingdom, although present stocks are low.

Coir. The only important world-producers of coir (coconut fibre) are India and Ceylon, where the industry is carried out as a part-time occupation of villagers, who also utilize a large proportion of the material. The mobilization of native labour for war purposes in these two countries has led to reduced coir production during the past eight years.

Rayon. The output of rayon yarn has been maintained in recent times, despite the collapse of Japan, by the large increase in production in the United States, which has more than doubled since 1941. By 1946, the United Kingdom had become the second largest producer and the second largest exporter. Rayon depends for its raw materials on the supply of wood pulp or cotton linters. The filaments are reeled to produce 'filament yarn' or spun on to spindles to produce 'staple fibre'. The former competes with natural fibres; the latter $s$ an intermediate product which is becoming increasingly important as an admixture to the natural fibres.

\section{OBITUARIES}

\section{Prof. F. A. A. Lacroix}

ON March 16 there passed out of the scientific life of Paris a great figure and one whose scientific writings have been read by mineralogists and geologists the world over for the past sixty years. François Antoine Alfred Lacroix, 'secrétaire perpetuel' of the Paris Academy of Sciences for thirty. four years and professor of mineralogy at the National Museum of Natural History during 1893-1936, was borm at Maçon on February 4, 1863, and died in Paris on March 16. He studied at the lycée of his native town, at the Sorbonne, and at the Collège de
France. He commenced to study pharmacy but soon was attracted to geology and mineralogy, and in 1887 was appointed 'préparateur' at the Collège de France and a collaborator on the French Geological Survey. Before he was thirty he succeeded Des Cloizeaux as professor of mineralogy at the Natural History Museum. He added many fine specimens of minerals and a superb collection of rocks to the Museum collections. In this he was assisted by many of his pupils, mining engineers and government officials in France's overseas possessions who, catching the enthusiasm of the master for his science, seem to have been ever ready to gather materials for his scientific work and for the national collections.

On his appointment to the Museum, Lacroix com. menced at once a great work on the mineralogy of France and her Colonies: its fourth volume was completed in 1913. In these volumes he described the associations and paragenesis of the minerals as well as their crystallography and optical properties. A separate work in three volumes on the mineralogy of Madagascar was published in 1922 and 1923. This included $a$ wealth of detailed petrology and many new andlyses of rocks as well as descriptions of the minerals. In this book he developed his classification of igneous rocks, a modified form of the American quantitative classification. In later years he devoted more time to petrology than to descriptive mineralogy, and published a great many papers describing the rocks of many regions, and introducing, sometimes in very brief papers, ideas of considerable importance. Meteorites and tektites-the mysterious glass bodies supposedly of meteoritic origin-were also subjects of his research and were described in important memoirs. To geologists Lacroix will be best known for his early work on the granite of the Pyrenees and its contact phenomena (1898-1900), and for the well-illustrated memoirs recording his observations on active volcanoes in several parts of the world, including especially Mt. Pelée, Vesuvius and Réunion.

In addition to all his mineralogical work, Lacroix devoted an immense amount of time to the affairs of the Academy of Sciences, working at the development of its library and the classification and enrichment of its archives, gathering together letters and other documents of great interest. He published biographies of many mineralogists. His two-volume history of the life of Déodat Dolomieu appeared in 1921 , and in 1928 a historical note on the distinguished occupants of the 'chair' of the section of mineralogy of the Academy from Nicolas Desmarest (1795) to Lucien Cayeux (1928).

In all his work Lacroix had a sympathetic and devoted companion in his wife, Catherine Fouqué, daughter of the geologist, Ferdinand A. Fouqué, with whom Lacroix worked in his early years. Madame Lacroix accompanied her husband on many of his travels, visiting with him many active volcanoes. Their married life was extremely happy, and their home had a charm which touched all who were admitted to their friendship and their hospitality. Madame Lacroix died in 1944 and Lacroix never completely got over it; but still he remained enthusiastic and immensely active, and went daily to the museum and the Academy. To the end of his life he was surrounded by devoted friends and colleagues. Many geological societies had done him honour during his life-time and many tributes have already been paid to his memory. The president of the Paris Academy of Sciences, in announcing Lacroix's death to the members, described him as a man who had 